\title{
MINING
}

DOI: $10.29202 /$ nvngu/2018-5/3

A. Saadoun ${ }^{1,2}$,

A. Hafsaoui ${ }^{1}$, Dr. Sc. (Tech.), Prof., Y. Khadri ${ }^{1}$, Dr. Sc. (Tech.), M. Fredj ${ }^{1,2}$

1 - Badji Mokhtar University, Annaba, Algeria, Algeria,

e-mail: abdoumines23@yahoo.com

2 - Abderrahmane Mira University, Bejaia, Algeria

\section{NUMERICAL MODELING OF SLOPE STABILITY IN CHOUF AMAR LIMESTONE QUARRY (M'SILA, ALGERIA)} cases.

Methodology. The study of slope stability was performed by the limit equilibrium method (LEM) through the SLIDE software, and numerical methods through PLAXIS and FLAC.

Findings. In this study, the presence of water in the marl layer has a heavy influence on the safety factor (SF), which allows for instability of the slope.

Originality. The originality of this work is based on two different approaches to determine the safety factor in the dry and wet cases through three methods, the limit equilibrium, finite element and finite difference methods (FEM, FDM).

Practical value. This study has shown that numerical modeling of the slope stability using three methods, LEM, FDM and FEM can be expected to produce similar results. The different methods indicate that the finite difference method in our case is the most efficient and can be used as a practical check for the other methods.

Keywords: slope stability, FD method, FE method, LE method, safety factor, Chouf-Amar quarry, numerical modeling

Introduction. Study of the stability of natural or artificial slopes is regularly carried out in order to measure the critical and effective slope safety factor (e.g. Quarrys, highway, and others). Therefore, the slope stability is a major problem in mining engineering.

The classification of slope movements is generally divided into four categories (e.g. planar, wedge, toppling, and circular failures) based on their geometrical nature and geotechnical conditions of the rock masses [1]. According to research conducted by several researchers, Gadri et al (2015) [2] shows the different sliding and causes that produce these failures [Planar failures occur along prevalent joints dipping toward the slope with strike near parallel to the slope face. Wedge failures occur along two joints from different families whose intersection dips toward the slope. Toppling failures occur along a prevalent family of joints, which dip against the slope with a strike near parallel to the slope face. Circular failures occur along slip paths].

Instability of rock masses. Rock instabilities occur when a number of factors come together and, for one reason or another, the precarious state of stability prevailing up to that point shifts to an unstable situation resulting in displacements of rocks characterized by their types (slip, flow, fall ...).

(C) Saadoun A., Hafsaoui A., Khadri Y., Fredj M., 2018
The calculation of stability can be done under two very different circumstances; before or after the movement is triggered. In the first case, the slope is apparently stable, the objective of the stability calculation is to define a sliding surface that would have the best chance of appearing. In other words, the stability calculation makes it possible both to assess the margin of safety of the slope with respect to the rupture, to define in the site the zone most threatened by the instability and to examine the influence of some works (earthworks, constructions, and so forth) on the margin of safety that has been defined for the slope virgin. This calculation step is, therefore, very important because it allows choosing the parameters necessary for the work and ensuring the stability on the whole (work and site).

Unlike the first case and when the movement has already appeared on the slope, the calculation of stability is done to assess the margin of safety that separates the current state of the site from the steady state. In this second case, the values of the parameters necessary to be introduced in the calculation are in principle given by the investigations already carried out on site, they are real values such as: the geometry of the surface of the sliding, the geotechnical characteristics of the massif and of the sliding surface, and so forth. In this case, the stability calculation is also of great interest because it allows the identification of the causes of the appearance of 
movement and to define the comfort devices necessary to limit the risk.

The stability of mine slopes remains one of the main issues that arise during open-pit mining. Slope stability has a direct influence on the safety of the work in the mine, the technological principles of exploitation, the total depth of the mine, drainage problems, and others.

Factors influencing slope stability in mining. According to many research studies, the different forms of rock slope instability depend on "internal" factors specific to the massif and "external" ones interacting with it and they are related to the nature, the morphology of the rock masses and the characteristics of the discontinuities that affect them.

In mining, the main factors influencing slope stability, namely the maximum slope angle that an embankment can accommodate, depend on a number of factors, the main ones being:

- the height of the bench;

- the nature of the land;

- groundwater;

- the method and phases of exploitation;

- geometrical factors (concavity or convexity of the edge of the slope);

- physical and mechanical proprieties of rock.

In this study, we based our work of the presence of water in the marl layer that has a heavy influence on the safety factor (SF), which allows for instability of the slope.

Influence of groundwater on slope stability. Water plays a very important role in slope stability. In general, the presence of water in a field lowers the safety factor.

The presence of water in the rock mass is also a key factor that directly and indirectly affects the behavior of fractured rock masses. Its indirect effects put aside, the water decreases the resistance of the discontinuities and therefore of the massif. Moreover, it increases the active loads on the massif or on the associated structures, which favors the instability, even the rupture of the massif or related structures. In relatively simple problems, it is possible to determine the water pressure distribution by hydraulic calculation at the level of the fractures and to use the concept of the effective stress. In fact, just as water affects the mechanical behavior of the massif, the mechanical response of the massif affects the hydraulic behavior of the fractures. The second objective of this thesis is the development of numerical tools to model the hydromechanical interaction and coupling at the discontinuities of rock masses.

Slope Stability Methods. Limit equilibrium methods (LEM). LEMs are the most commonly used approaches in slope stability analysis. The fundamental assumption in these methods is that failure occurs through sliding of a mass along a slip surface.

Finite element and finite difference methods (FEM, $\boldsymbol{F D} \boldsymbol{M})$. Finite element and finite difference methods are powerful numerical tools for solving many engineering problems and mathematical physics. Due to rapid development of computer technology, FEM and FDM have gained increasing popularity over the traditional methods in geotechnical engineering. The finite element and finite difference methods are numerical methods used for slopes stability studies, the values of safety factors (SF) were obtained by the Technique of Shear Strength Reduction (TSSR). Stability problems in large-scale open-cast often involve complexities that are not easily addressed by limit equilibrium methods LEM. Therefore, using numerical methods, such as the finite element and finite difference methods, provides the engineer with an opportunity to conduct more comprehensive and sound slope stability analyses. While LEM is revealed to be a simple method for assessing slope stability, it has its own limitations. For example, the method does not take into account the stress and the deformation in the rock mass. However, FEM and DFM are based on TSSR and can compensate for LEM limits in slope stability analysis [3]. The FEM, which has gained wide importance in the field of rock engineering, has the capability to model any complex problem with ease. The TSSR is more preferred because it keeps on lowering the values of shear strength parameters until the solution converges or material starts to show the signs of failure [4]. Shear strength parameters like cohesion and angle of internal friction are very important in slope failure activity because with time material degrades due to water and temperature variation. This will cause lowering of strength, particularly the resisting strength, which holds the material against failure. Moreover, such parameters show a range in values spatially and representing such parameters with a single value may not be appropriate [5].

Location of Limestone Quarry. The Wilaya of M'sila is located in the Central East parties of the Algeria, $250 \mathrm{~km}$ southeast of the capital Algiers; it borders with the provinces of Bouira and Bordj Bou Arreridj to the north, east Batna, Biskra southeast, Djelfa and Medea west as shown in Fig. 1.

As for the layout of the Chouf Amar deposit, it is in the form of a directional monoclonal longitudinal lying under a dip of 10 to 15 degrees plunging towards the SSE.

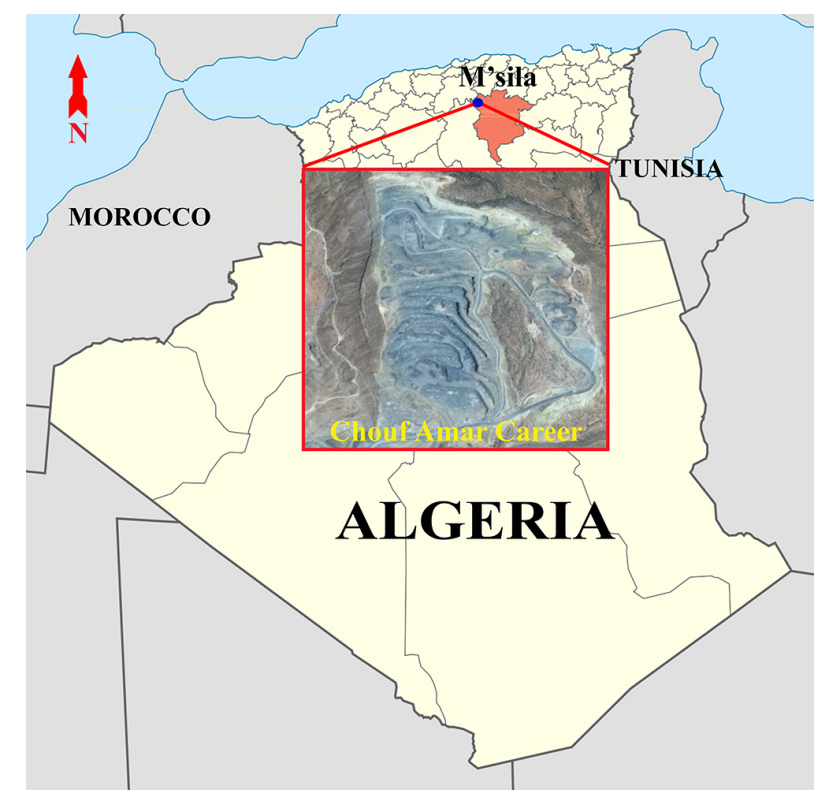

Fig. 1. Location map of limestone Quarry of Chouf Amar 
On the tectonic level of this deposit a NW-SE oriented fault splits the deposit in two sectors (West Sector and East Sector).

The exploitation of limestones at the Chouf Amar quarry (Wilaya of M'sila) started in 2003 with an annual production capacity of 4.2 million tons per year. The deposit was studied in detail by the Center for Studies and Technological Services of the Building Materials Industry (CETIM).The total reserve evaluation before the start of operation was estimated at 232 million tones with a life span of 50 years, the planning of the Hammam-Dalaa cement plant is based mainly on the improvement forecasts operating techniques and the quality of products to meet the needs of the market. However, previous studies by the center for studies (CETIM) showed the existence of significant groundwater that affects the stability of the mine and thus affect the exploitation process.

Modeling of stability at the Chouf Amar quarry. Several studies and stability analyzes have been done at the edge of the limestone quarry (Chouf-Amar) leading us to consider it to be a sensitive area of stability perspective. Repetitive production operations can weaken and reduce edge stability. Our study is to evaluate and model the slope stability of limestone quarry by limit equilibrium and numerical methods. This assessment is a medium-term evaluation for the steps with advancement for the year (2017-2018) as shown in the topographic plan, and more specifically for the steps from which the cracks have been removed and implanted to determine well. Their positioning and their dip are important for the stereographic evaluation and calculation of the SF. Fig. 2 shows a sliding in quarry of Chouf Amar between two levels.

Stereographic evaluation of the quarry of Chouf Amar. Stereography methods are one of the methods used to evaluate the slope stability in quarrys.

At the Chouf Amar quarry, the rocks are very cracked, especially, the northern side edge containing a set of cracks, adding to it a layer of marl with variable thickness, which allow for water infiltration; the latter can lead to the development of large hydraulic pressure, unfavorable to stability [6] as illustrated by Fig. 3 .

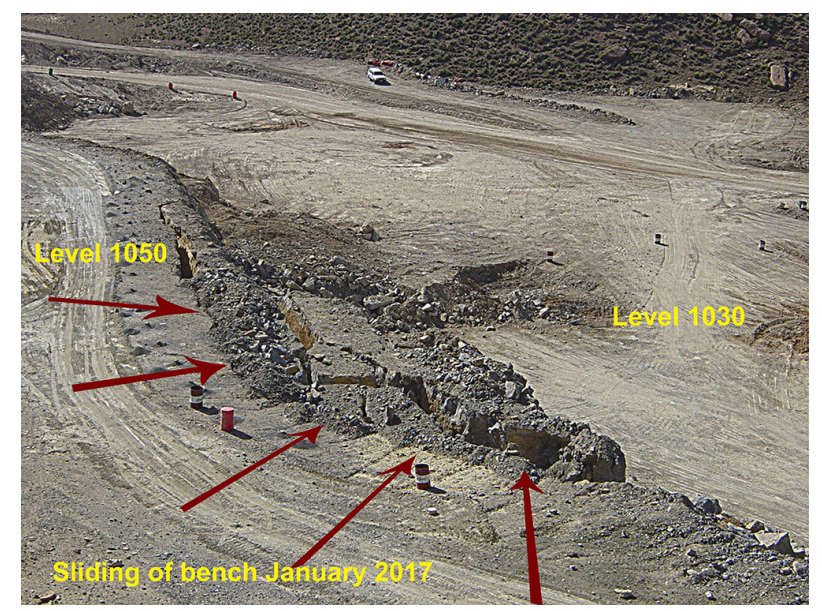

Fig. 2. Sliding of bench January 2017 in quarry of Chouf Amar

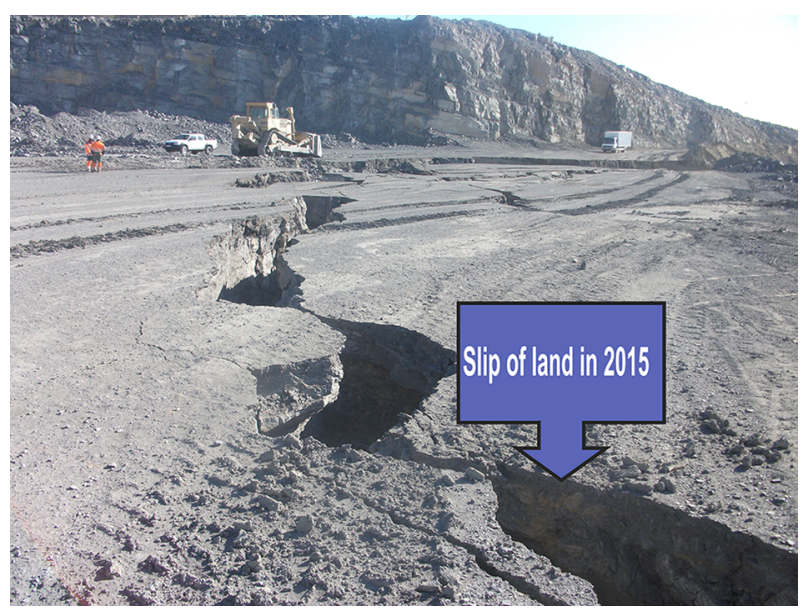

Fig. 3. Quarry of Chouf Amar after sliding [6]

In the stereographic evaluation we chose two levels of 1050 and 1030 because Chouf Amar's quarry has two sliding planes, one following the intercalations of dominant marl on the limestone layer and the other plane following the different cracks having the clay fines as filling.

The calculation of the safety factor is made taking into account several parameters and in several states of the slope (presence or lack of the crack of crest, being dry or wet and others)

Stability of Level 1050. The Stereographic representation of slope and cracks of this level is represented in Fig. 4.

The azimuth and dip of existing cracks in this level are presented in Table 1.

The stereographic evaluation of this level shows there will be a possibility of several flat landslides for dip-like cracks, and another possibility for wedge slip from the intersection of two planes within the critical zone.

Stability of Level 1030. The azimuth and dip of existing cracks in this level are presented in Table 2.

The Stereographic representation of slope and cracks of this level is represented in Fig. 5.

The stereographic evaluation of this level shows only one possibility of a plane slip and a single possibility of wedge slip.

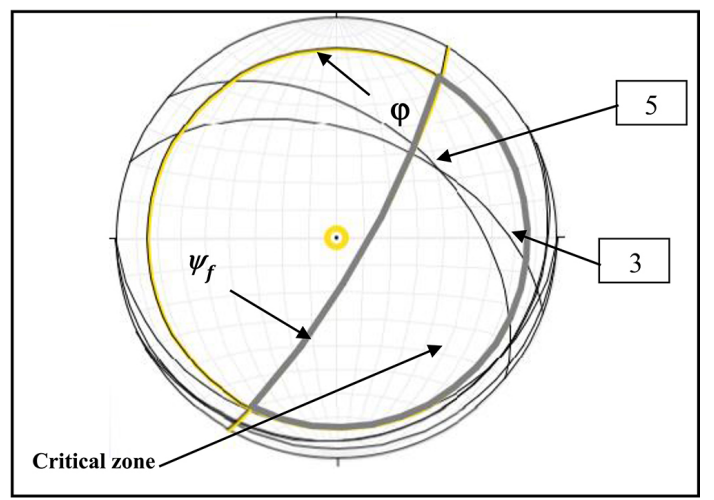

Fig. 4. Stereographic representation of slope and cracks at level 1050 in quarry of Chouf Amar 
Table 1 finite element, finite difference methods through PLAX-

Azimuth and dip of existing cracks in level 1050

\begin{tabular}{|c|c|c|}
\hline \multicolumn{3}{|c|}{ Level 1050 } \\
\hline plane & azimuth & dip \\
\hline slope & N30 & $80 \mathrm{SE}$ \\
\hline 1 & $\mathrm{~N} 270$ & $5 \mathrm{SE}$ \\
\hline 2 & $\mathrm{~N} 240$ & $10 \mathrm{SE}$ \\
\hline 3 & $\mathrm{~N} 310$ & $45 \mathrm{NE}$ \\
\hline 4 & $\mathrm{~N} 270$ & $15 \mathrm{SE}$ \\
\hline 5 & $\mathrm{~N} 290$ & $50 \mathrm{NE}$ \\
\hline 6 & $\mathrm{~N} 245$ & $10 \mathrm{SE}$ \\
\hline
\end{tabular}

Table 2

Azimuth and dip of existing cracks in level 1030

\begin{tabular}{|c|c|c|}
\hline \multicolumn{3}{|c|}{ Level 1030 } \\
\hline plane & azimuth & dip \\
\hline slope & N30 & $80 \mathrm{SE}$ \\
\hline 1 & $\mathrm{~N} 300$ & $50 \mathrm{SE}$ \\
\hline 2 & $\mathrm{~N} 300$ & $70 \mathrm{NE}$ \\
\hline 3 & $\mathrm{~N} 300$ & $80 \mathrm{NE}$ \\
\hline 4 & $\mathrm{~N} 310$ & $85 \mathrm{SE}$ \\
\hline
\end{tabular}

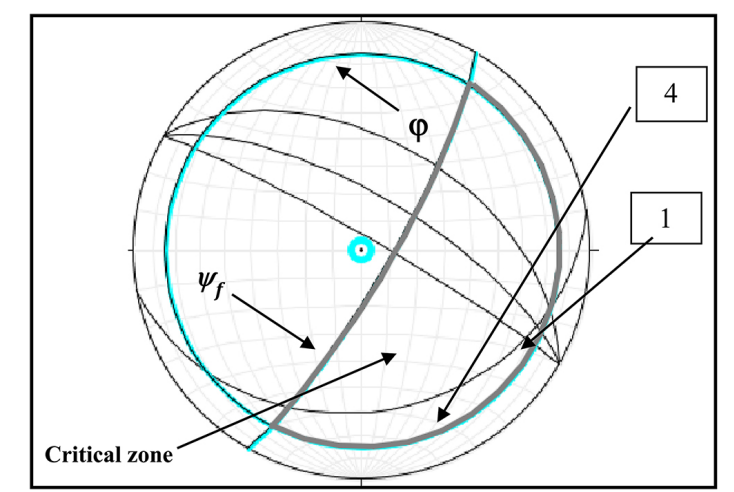

Fig. 5. Stereographic representation of slope and cracks in level 1030 at the quarry of Chouf Amar

Methodology. According to the study carried at the Chouf-Amar quarry, several factors led to the slippage of which the most plausible reasons could be the intercalation of marl layers between the limestone formations. The infiltration of water into the marl beds produces a reduction in the safety factor.

In this study, the objective of the present work is to investigate the comparative performance of three different software packages, in the context of slope stability between two levels of bench height of 20 meters in quarry limestone of Chouf Amar. More specifically, the widely used geotechnical software FLAC 2D, PLAX and SLIDE. The modeling was performed by the limit equilibrium method through the SLIDE software, the

IS and FLAC, respectively.

The quarry of Chouf Amar is excavated as benches with slope angles of 70 to $85^{\circ}, 20 \mathrm{~m}$ in height. Simple slope geometry is used for our case of stability analysis described in this section. The slope has a height of $20 \mathrm{~m}$ with marl intercalations of average thickness of $2 \mathrm{~m}$. The blocks of rock in the model are represented in Fig. 6.

The properties of the rock block and the properties of marl intercalation presented by the Mohr-Coulomb model are listed in Table 3.

Two cases of slope stability are evaluated. The first case includes limestone with dry marl intercalation, and the other cases include limestone with wet marl intercalation.

Results and Discussion. Modeling of slope stability with software FLAC. Marl interlayers provide pressure on the rotating surfaces of the blocks. The blocks pushed by their own weight, turn towards the front of the slope; Fig. 7 shows the fracture surface this case. The calculated safety factor is 1.17 .

Fig. 8 shows the break mode. The calculated safety factor is 0.83 . The direction of the vectors of displacements is the same one as the dip of the marl intercalations, as one can notice there is great displacement of the front, the maximum value of displacements is equal to $4.48 \mathrm{~m}$ which leads to a sliding.

Modeling of slope stability with software PLAXIS. Depending on the result of the safety factor according to Fig. 9, the finite element method (Plaxis) shows that the slope quarry of Chouf Amar is unstable and that the rupture line is located more precisely at the interface limestone marl with the total displacements significant, the safety factor in this dry case is 1.19 .

In the wet case the failure surface in Plaxis shows sharp transition in the upper part of the slope due to for-

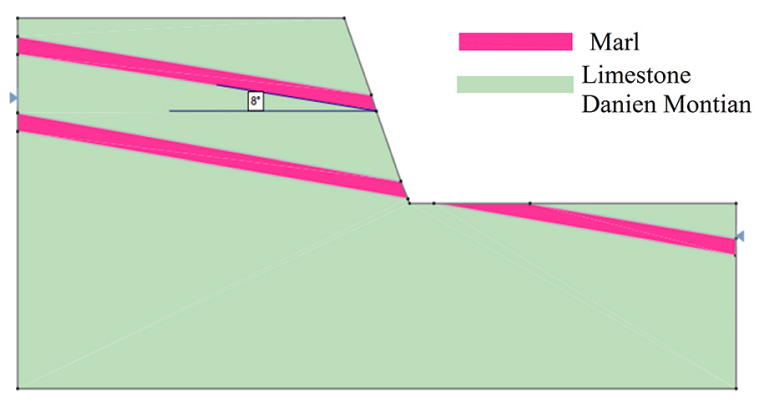

Fig. 6. Geometrical model used in the study

Table 3

Geotechnical parameters of rocks

\begin{tabular}{|l|c|c|c|c|c|c|}
\hline \multirow{2}{*}{ Rocks } & $R_{c}$ & $\gamma_{d}$ & $E$ & $c$ & $\varphi$ & $\psi$ \\
\cline { 2 - 8 } & $\mathrm{MPa}$ & $\mathrm{kN} / \mathrm{m}^{3}$ & $\mathrm{kPa}$ & $\mathrm{kPa}$ & $\left(^{\circ}\right)$ & $\left(^{\circ}\right)$ \\
\hline $\begin{array}{l}\text { Limestone } \\
\text { Danian Montian }\end{array}$ & 20.11 & 26 & 24000 & 3100 & 27 & 7 \\
\hline Marl & 8.93 & 21 & 900 & 100 & 12 & 0 \\
\hline
\end{tabular}

$R_{c}$ : Compressive Strength, $\gamma_{d}$ : Unit weight, $E$ : Young's modulus, $c$ : cohesion, $\varphi$ : Internal friction angle, $\psi$ : dilatancy 


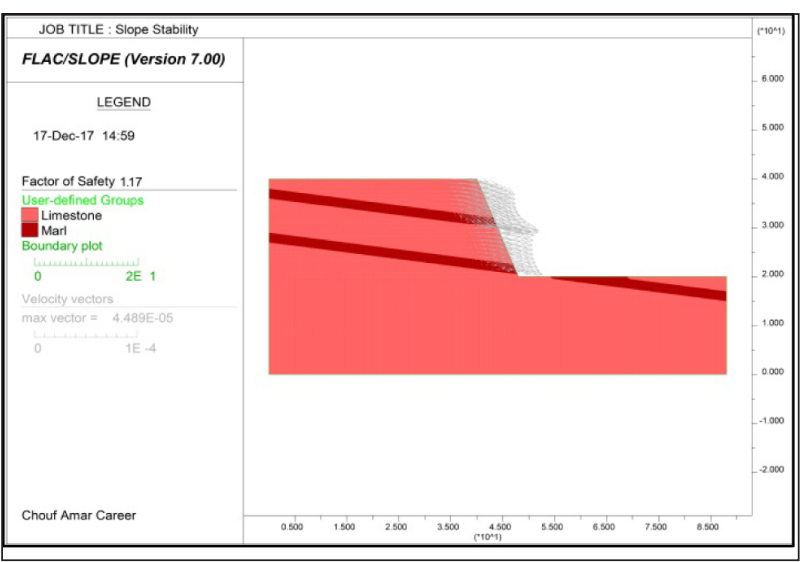

Fig. 7. The shear stress and the vectors in the presence of intercalations marl (dry case)

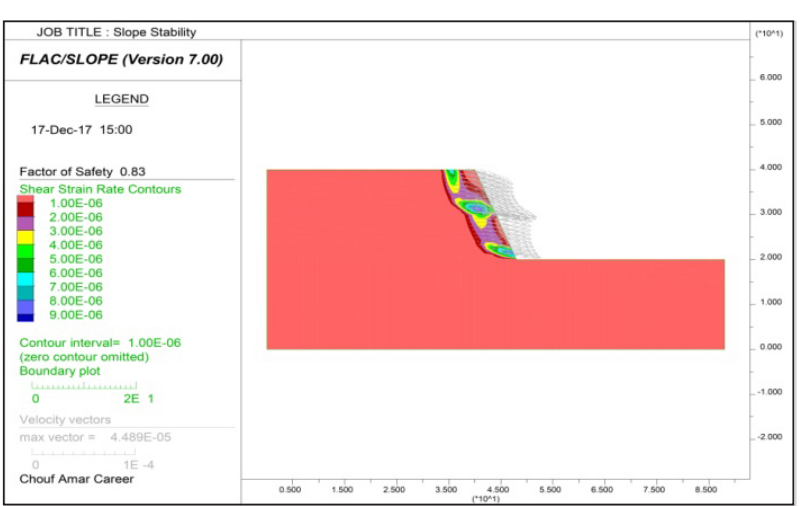

Fig. 8. Wet case: An analyzed slope showing velocity vectors of the grains of rock mass

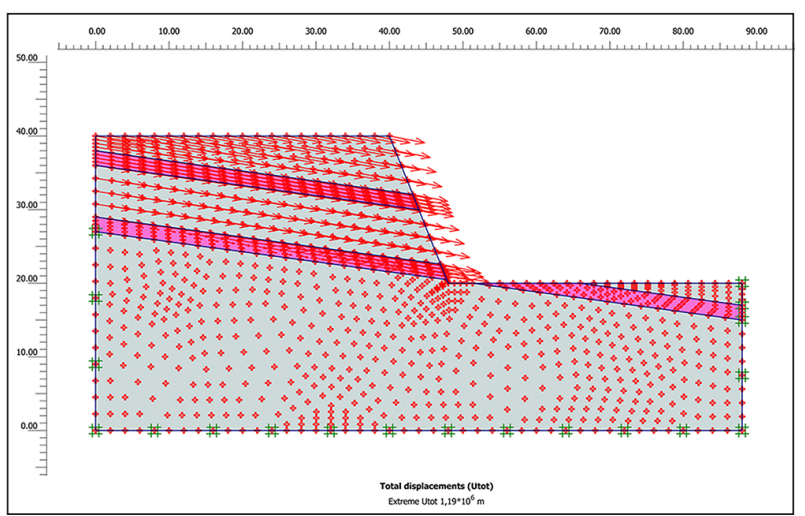

Fig. 9. Total displacements in dry case

mation of the intercalation marl with safety factor of 0.91 as it is represented in Fig. 10.

Modeling of slope stability with software SLIDE. The same critical failure surface is obtained from Slide with the corresponding safety factor, $\mathrm{Sf}=1.20$, which is practically almost the same value as the one computed in two methods and it is represented in Fig. 11.

In wet case the modeling of slope is conducted with Slide and Fig. 12 represents a surface of the slices with safety factor equal 0.89 .

The corresponding safety factor of two cases calculated by three methods is summarized in Table 4 .

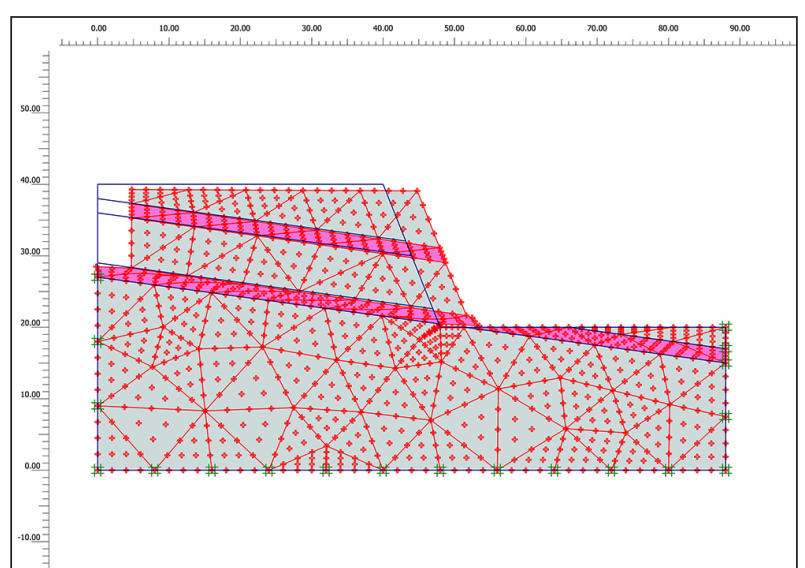

Fig. 10. Significant sliding in wet intercalation marl

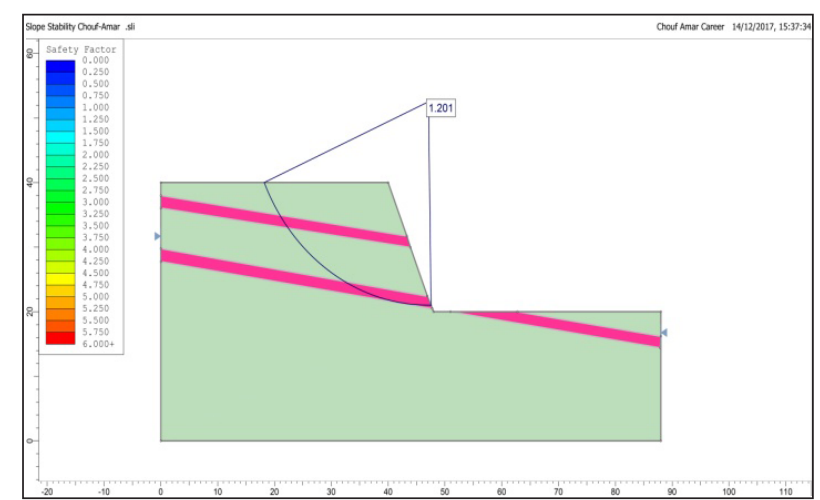

Fig. 11. The surface of the slices

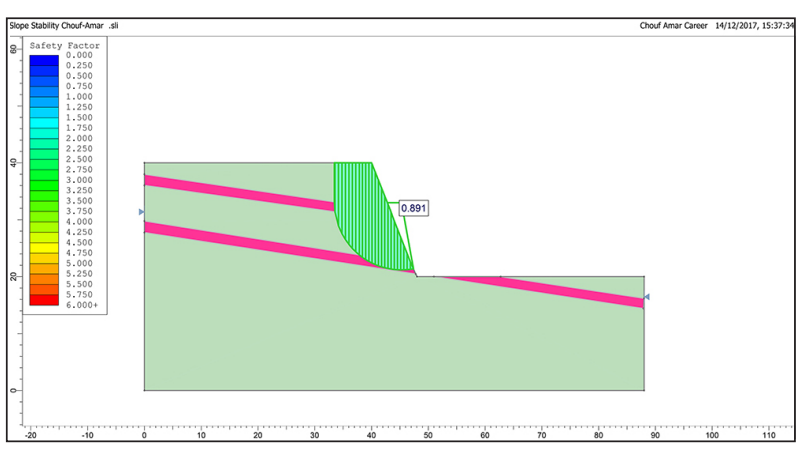

Fig. 12. Surface of the slices in Chouf Amar quarry

Conclusions. Slope stability modeling in quarry of Chouf Amar is affected by using three different numerical software: FLAC (Finite difference), Plaxis (Finite elements) and Slide (Limit equilibrium).

In this study the presence of water in the marl interlayer influences the safety factor and therefore the stability of the

Table 4

Safety factor calculated by three software

\begin{tabular}{|l|c|c|}
\hline \multirow{2}{*}{ Methods } & \multicolumn{2}{|c|}{ Safety Factor } \\
\cline { 2 - 3 } & dry case & wet case \\
\hline Flac & 1.17 & 0.83 \\
\hline Plaxis & 1.19 & 0.91 \\
\hline Slide & 1.20 & 0.89 \\
\hline
\end{tabular}


slope. We noticed that the results of the safety factor values are similar with instability in the case of limestone tiers containing marl intercalations especially in the wet case.

The finite difference method (FDM) justified and validated the other methods (FEM and LEM) for evaluation quarry stability in two cases of intercalations marl (dry and wet).

Recommendations. To study the stability of slopes in open mine, it is recommended to use more than one method and compare the results to select the optimal ones.

Acknowledgments. The authors would like to thank the staff of the laboratory (Natural resources and planning, University of Annaba, Algeria). Moreover, special thanks to Prof. A. Hafsaoui (Annaba university, Algeria) for her objective comments and correction and the author would like to acknowledge the availability and help of F. Mohamed.

\section{References.}

1. Wang, G., Wu, F. and Ye, W., 2013. Stability analysis for toppling failure of unstable rock in three gorges reservoir area, China. Rock Charact. Model Eng Des Methods, pp. 431-435. DOI:10. 1201/b14917-77.

2. Gadri, L., Riheb, H., Zahri, F., Benghazi, Z., Boumezbeurm, A., Laid, B. M. and Raïs, K., 2015. The quarries edges stability in opencast mines: a case study of the Jebel Onk phosphate mine, NE Algeria. Arab J Geosci, 8, pp. 8987-8997. DOI: 10.1007/s12517-015-1887-3. 3. Jiang, Q., Qi, Z., Wie, W. and Zhou, C., 2015. Stability assessment of a high rock slope by strength reduction finite element method. Bull. Eng. Geol. Environ, 74, pp. 1153-1162.

4. Kainthola, A., Singh, P. K., Wasnik, A.B., Sazid, M. and Singh, T.N., 2012. Finite element analysis of road cut slopes using Hoek and Brown failure criterion. Int. J. Earth Sci. Eng., 5(5), pp. 1100-1109.

5. Gupta, T., Rai, R., Jaiswal, A. and Srivastava, B. K., 2014. Sensitivity Analysis of Coal Rib Stability for Internal Mine Dump in Opencast Mine by Finite Element ModeIling. Geotech. Geol. Eng., 32, pp. 705-712.

6. Saadoun, A., Hafsaoui, A. and Fredj, M., 2017. Landslide Study of Lands in Quarrys. Case Chouf Amar - M'sila, Algeria. Contemporary Issues in Geoenvironmental Engineering, Sustainable Civil Infrastructures. DOI: 10.1007/978-3-319-61612-4_3.

\section{Чисельне моделювання стійкості схилу у вапняковому кар'єрі Шуф Амар (М'сіла, Алжир)}

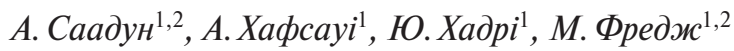

1 - Університет Баджи Мохтар, м. Аннаба, Алжир, e-mail: abdoumines23@yahoo.com

2 - Університет Абдеррахмане Міра, м. Беджая, Алжир

Мета. Числове моделювання стійкості схилу вапнякового кар'єру в сухих і вологих умовах.

Методика. Вивчення стійкості схилу проводилося за допомогою методу граничної рівноваги (МГР) з використанням програми SLIDE, а також чисельного методу з використанням PLAXIS і FLAC.
Результати. У даному дослідженні присутність води у шарі вапняку має сильний вплив на коефіцієнт безпеки, що сприяє нестабільності схилу.

Наукова новизна. Новизна даної роботи полягає у двох різних підходах до визначення коефіцієнта безпеки в сухих і вологих умовах за допомогою трьох методів: граничної рівноваги, кінцевих різниць і кінцевих елементів (МКР, МКЕ).

Практична значимість. Дане дослідження показало, що числове моделювання стійкості схилу з використанням трьох методів МГР, МКР і МКЕ призводить до близьких результатів. Різні методи вказують, що метод кінцевих різниць у нашому випадку найбільш ефективний і може бути використаний в якості практичної перевірки інших методів.

Ключові слова: стійкість схилу, метод КР, метод КЕ, метод ГР, коефіцієнт безпеки, кар'єр Шуф Амар, числове моделювання

\section{Численное моделирование устойчивости склона в известняковом карьере Шуф Амар (Мсила, Алжир)

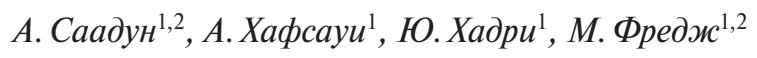 1 - Университет Баджи Мохтар, г. Аннаба, Алжир, e-mail: abdoumines23@yahoo.com \\ 2 - Университет Абдеррахмане Мира, г. Беджая, Алжир}

Цель. Числовое моделирование устойчивости склона известнякового карьера в сухих и влажных условиях.

Методика. Изучение устойчивости склона проводилось с помощью метода предельного равновесия (МПР) с использованием программы SLIDE, а также численного метода с использованием PLAXIS и FLAC.

Результаты. В данном исследовании присутствие воды в слое известняка имеет сильное влияние на коэффициент безопасности, что способствует нестабильности склона.

Научная новизна. Новизна данной работы основана на двух разных подходах к определению коэффициента безопасности в сухих и влажных условиях с помощью трех методов: предельного равновесия, конечных разностей и конечных элементов (МКР, МКЭ).

Практическая значимость. Данное исследование показало, что числовое моделирование устойчивости склона с использованием трех методов МПР, МКР и МКЭ приводит к близким результатам. Разные методы указывают, что метод конечных разностей в нашем случае наиболее эффективен и может быть использован в качестве практической проверки других методов.

Ключевые слова: устойчивость склона, метод КР, метод КЭ, метод ПР, коэффициент безопасности, карьер Шуф Амар, числовое моделирование

Рекомендовано до публікацї Аісса Бенселгуб. Дата надходження рукопису 26.09.17. 